\title{
Persuation of Teacher Communication in Preventing the Danger of Drug Abuse on High School Students
}

\author{
Abrar Adhani', Akhyar Anshori ${ }^{2}$ \\ University of Muhammadiyah Sumatra Utara (UMSU), Indonesia \\ abraradhani@umsu.ac.id, akhyaransori@umsu.ac.id
}

\begin{abstract}
The teacher is one part that has an important role in building the character and mentality of students. High school students are part of the human growth phase in adolescence. Teenagers are part of the leadership baton. At a young age this is also targeted for criminals, including drug traffickers, because adolescence is identical to the age of selfdiscovery. The methodology carried out in this study with the research design combination of qualitative and quantitative approaches with dominant-less dominant design model. The methodology carried out in this study is divided into 2 parts, the first through the survey methodology and the second through in-depth discussion to obtain results related to the study Drug prevention communication planning for high school students. The results of this study indicate that high school students in Medan City have received information regarding abuse of drug use. Drug abuse can cause physical or psychological dependence. Knowledge that is owned by high school students in Medan City should be followed up by carrying out positive activities. School is a part of the community that determines student attitudes. Activities in school activities must always be in sync with existing development conditions. Schools are not just a learning medium, but schools must play an active role in raising awareness for their students.
\end{abstract}

Keyword: persuasive communication; drug prevention; high school students

\section{Introduction}

Drug problems have recently become a hot issue in the midst of society, where victims who fall are the result of using these materials incorrectly, or in other words abusing narcotics and illegal drugs is getting more and more days. Even more worrying that drug users have spread at a young age, not a few of those who started using drugs are still in elementary, middle and high school. It can be imagined what is the fate of this nation if its young seedlings have been poisoned by drugs. Teenagers, is a period of change from what children originally headed towards maturity. This period is also often called the transition period or the search for someone's identity. At this time, teenagers will begin to deal with world problems that they may not have faced before in childhood. Love, friendship, conflict, competition, etc., are part of their teenage years before they finally get to know the world in adulthood.

Teenagers are indeed vulnerable to new things. They sometimes cannot distinguish between good things and bad things. Not a few teenagers who actually undergo inappropriate things (irregularities), such as free sex, drugs, drunkenness, gambling, brawl and soon.

Approximately 30\% of Indonesia's population are adolescents aged 10-24 years. for the city of Medan itself, the population in the 10-24 year age group reached 641,615 people based on Medan data in 2012 figures or around 30.30\%. This age is an age that has great 
potential for future regional development. And at this age are also the main targets in drug abuse. This will be a problem when we know that drug crime activities are neatly organized and international activities that operate with a closed and confidential network system. In addition, many of the students still do not understand the dangers of narkoba. So that they are easily fooled by persuasion from irresponsible people. In this context, the broad role of the people is highly expected to be able to cooperate and synergize in promoting the anti-drug movement. This research is directed to obtain appropriate planning strategies in the prevention of drug communication among high school students in Medan City.

\section{Literature Review}

\subsection{Interpersonal Communication in Improving Student Understanding of the Bad Impact of Drug Use}

According to DeVito (Liliweri, 1991), interpersonal communication is the sending of messages from someone and is received by another person or group of people with immediate effects and feedback. While Effendy (1986) suggested that essentially interpersonal communication is communication between the communicator and a communicant. This type of communication is considered to be the most effective in terms of changing one's attitude, opinion, or behavior, because of its dialogical nature, in the form of conversation. Backflow is direct. The communicator knows the response of the communicant right away, when the communication is launched. The communicator knows for sure whether the communication is positive or negative.

According to its nature, interpersonal communication can be divided into two types, namely Dyadic Communication and Small Group Communication. communication is a process of communication that takes place between two people in face-to-face situations both in the form of conversation, dialogue, and interview. Small group communication is the process of communication that takes place between three people or more face to face, where members interact with one another (Cangara, 2009).

\subsection{AIDDA Theory in Doing Persuasive Approaches to Students}

Starting with arousing attention is the beginning of successful communication. According to Wilbur Schramm (Effendy; 1993) that attention is the effect in the initial stage of the communicant. Success or failure to attract attention is greatly influenced by several factors;

1) The ability of the communicator to master the message

2) Able to empathize

3) Communicators are people who are experts in their fields

Formula AIDDA is an abbreviation of persuasive communication stages (Effendy, 1986). The explanation is as follows:

A- Attention- Perhatian

I- Interest- Ketertarikan

D- Desire- Hasrat

D- Decision- Keputusan

A-Action- Tindakan 
The formula is often also called A-A Procedure as an abbreviation of Attention Action - Procedure, which means that the communicant in carrying out the activity begins first by growing attention. Based on the AIDDA formula, persuasive communication is preceded by efforts to arouse attention. If attention has been successfully raised, now follows efforts to foster interest. This effort was successful by expressing matters relating to the interests of communicants. Therefore the communicator must know who the communicator is facing, "Know your audience, know your audience. The next stage is to bring up the desire for communication to make an invitation, persuasion, or seduction of the communicator. Here the emotional appeal (emotional appeal) needs to be displayed by the communicator, so that at the next stage the communicant makes the decision to do an activity as expected thereof.

Procedures for phasing out persuasive communication, as explained above can be known in a few moments, but can also be for years. From the communication process it appears, that the phasing which starts from the effort to arouse attention to create activities, lasts only briefly. If viewed from a psychological standpoint, the component of changes that occur in the AIDDA model can also be viewed from the components of attitude changes that occur in humans due to exposure to messages (Rachmat; 2002), namely:

1) Cognitive: The message delivered is aimed at the mind of the communicant. This is done so that the communicant knows and understands the message delivered. This is the same as the attention to the AIDDA model.

2) Affective: At this stage the communicator's goal is not only so that the communicant is moved so that certain feelings arise such as the interest arising from attention.

3) Behavioral: The impact that arises is in the form of actions or activities. This has begun to be seen in the decision making process.

\section{Methods of The Research}

Perception Research High school students about the socialization of drug abuse in Medan City are carried out with a quantitative descriptive approach. This approach was chosen in order to analyze data by describing or describing data that has been collected as it is without intending to make conclusions that apply to the general or generalization (Sugiyono, 2010). The sampling technique in this study was conducted with a random sampling model. The data that has been collected through questionnaires or questionnaires is then analyzed descriptively.

\section{Research Results and Discussion}

Table 1. Knowledge of Respondents and Information Sources

\begin{tabular}{cccccc}
\hline \multirow{2}{*}{ CHARACTERISTICS } & \multicolumn{3}{c}{ RESPONDENT } \\
\multicolumn{2}{r}{} & & Man & & Woman \\
Get Information & Yes & 318 & 92,17 & 291 & 84,35 \\
about Drugs & No & 27 & 7,83 & 27 & 7,83 \\
& Total & $\mathbf{3 4 5}$ & $\mathbf{1 0 0}$ & $\mathbf{3 1 8}$ & $\mathbf{1 0 0}$ \\
Source of & Parents & 43 & 13,52 & 33 & 11,34 \\
Information & Teacher & 37 & 11,64 & 69 & 23,71 \\
Related to Drugs & Friend & 26 & 8,18 & 33 & 11,34 \\
& Religious / & 49 & 15,41 & 24 & 8,25 \\
\hline
\end{tabular}




\begin{tabular}{ccccc}
\hline community & & & & \\
leaders & & & & \\
Extension agent & 23 & 7,23 & 21 & 7,22 \\
Television & 105 & 33,02 & 93 & 31,96 \\
Radio & 9 & 2,83 & 0 & 0 \\
Newspaper & 0 & 0 & 3 & 1,03 \\
Books / & 6 & 1,89 & 0 & 0 \\
Magazines & 20 & 6,29 & 15 & 5,15 \\
Internet & $\mathbf{3 1 8}$ & $\mathbf{1 0 0}$ & $\mathbf{2 9 1}$ & $\mathbf{1 0 0}$ \\
\hline Total & & & &
\end{tabular}

Source: 2017 Research Results

From the results of the study as can be seen in table 1 shows that $91.86 \%$ of respondents had obtained what was meant by drugs. The results showed that $31.96 \%$ of respondents obtained information related to drugs through the shows presented by television. This shows that respondents receive information through mass communication, while through interpersonal communication and organizational communication is classified as less often to be able to provide understanding to respondents about the dangers of drugs.

Table 2. Respondents' Attitudes About the Most Important Role in Drug Prevention Is Attention and Family Involvement.

\begin{tabular}{ccc}
\hline & frequency & percentace \\
\hline Strongly agree & 483 & $72,85 \%$ \\
Agree & 156 & $23,53 \%$ \\
Strongly agree & 15 & $2,26 \%$ \\
Strongly Disagree & 9 & $1,36 \%$ \\
Total & 663 & $100,00 \%$ \\
\hline
\end{tabular}

Source: 2017 Research Results

According to the table 2 that, respondents who strongly agree with attention / family involvement is a very important role to prevent young people from drug abuse as many as 483 people (72.85\%), which answered agree $156(23.53 \%)$, and respondents who answered no agree and strongly disagree 24 respondents (3.62\%). From these results it can be seen that respondents strongly agree that family attention and involvement play a role in preventing drug abuse. The complete family situation and the role of each parent to monitor the development of adolescents greatly influences adolescents not to behave deviantly. Good and smooth communication, having time to be with all family members and attention, so that the atmosphere of the house feels calm and warm. Such family harmony will reduce the busyness of teenagers outside who can influence them to act deviantly. The results of this study indicate that high school students in Medan City have received information related to abuse of drug use. Drug abuse can cause physical or psychological dependence. Knowledge that is owned by high school students in Medan City should be followed up by carrying out positive activities. Mr. Muhardi, who became one of the informants in this study, emphasized that school is a part of the community that most determines students' attitudes. Activities in school activities must always be in sync with existing development conditions. Schools are not just a learning medium, but schools must play an active role in raising awareness for their students. 
In communicating with students, teachers pay attention to every word spoken by the teacher because all the behaviors shown by the teacher are imitated by students. In the process of education or teaching in schools the teacher has a very important role in the development of student behavior. Drug problems are conveyed through existing information so that students are able to clearly understand the problem. The teacher has an obligation to be able to pay attention to each student's activities during the hours at school. This attention is shown by the shortcomings of communication carried out by teachers towards students who have problems, both in school, in their families and in their playmates. Students' knowledge about the dangers of drug abuse gave birth to an attitude to never try drugs, although there were still around $2 \%$ of respondents who said they still wanted to try drugs. This shows that the knowledge possessed is not in line with what should be done. This is where the role of the school is very decisive, the school as an institution and means of socialization is a very appropriate medium to always remind and encourage students to always stay away from drug abuse, this can be done by the school through various methods, both in lectures, outdoor media and other activities. In addition to the school, the family is also an important part in supporting student involvement in drugs. The complete family situation and the role of each parent to monitor the development of adolescents greatly influences adolescents not to behave deviantly. Good and smooth communication, having time to be with all family members and attention, so that the atmosphere of the house feels calm and warm. Such family harmony will reduce the busyness of teenagers outside who can influence them to act deviantly. In everyday relationships, adolescents tend to be more influenced by peer invitations than what parents say. Although the time spent with family is more than with peers, but peers more influence the activities and actions of the respondents. Therefore forming or compiling peers can be positive if directed to other positive activities and activities. This can be seen from the respondents' answers which state that peers always remind respondents of the dangers of drug abuse. Given the rampant narcotics circulation in Indonesia, it seems that the law in Indonesia does not make them (dealers or bookies) deterred, there is always the narcotics in Indonesia.

This is our duty and obligation as parents to supervise and be more aware of our children in association. Keep an eye on children's behavior and lifestyle. Parents must be sensitive to changes in the attitudes of children who, if they are involved in narcotics use, will be seen very clearly. We deserve and are obliged to protect and protect them from such attacks. As soon as they fall, it's a big problem later on. If narcotics are used continuously or exceed the prescribed dose, it will cause dependence. This addiction will cause physical and psychological disorders, due to damage to the central nervous system (CNS) and body organs such as the heart, lungs, liver and kidneys. The impact of narcotics abuse on a person depends on the type of narcotics used, the personality of the user and the situation or condition of the user. In general, the impact of drug addiction can be seen in a person's physical, psychological and social condition. Prevention efforts against the spread of narcotics, especially among students, should be our shared responsibility. In this case all parties including parents, teachers, and the community must play an active role in being aware of the threat of drugs to our children. The more concrete efforts that we can do are to collaborate with the authorities to conduct counseling about the dangers of drugs, or maybe to hold Sudden Raids Routinely.

Then mentoring from the parents of the students themselves by giving attention and affection. The school must conduct strict supervision of the movements of their students, 
because usually the spread (transactions) of drugs often occur around the school environment. No less important is that moral and religious education must be emphasized to students.

Because one of the causes of the fall of children into this vicious circle was the lack of moral and religious education they absorbed, so that even this disgraceful act, they finally lived. Therefore, from now on, we as educators, teachers, and as parents, must be alert and alert, the dangers of drugs that can ensnare our children at any time. With the aforementioned efforts, let us guard and supervise our students, from the dangers of narcotics, so that our hope to spawn a smart and tough generation in the future can be realized well.

\section{Conclusion}

Based on the results of research conducted in connection with the study of drug prevention communication planning for high school students in Medan, conclusions can be drawn as follows:

1. Based on the results of research findings that respondents know about drug information and the effects of drug abuse carried out. Television shows, both advertisements and other information, are the main references for respondents to find out information about drugs and the impact of their abuse.

2. The results also show that approximately $97 \%$ of respondents expressly stated that they would never try using drugs, even though there were still around 3\% who would try using drugs. With the attitude of respondents, around 53\% said that drug users must be isolated from the community.

3. The teacher is a part that cannot be forgiven in shaping student behavior and behavior. Persuasive communication by the teacher by being gentle, providing information about drug abuse in fact, and giving attention to all students is intended so that students understand more about how the effects of drug abuse occur.

4. The most important role in drug prevention is family attention and involvement in supporting students' positive activities. The complete family situation and the role of each parent to monitor the development of adolescents greatly influences adolescents not to behave deviantly. Good and smooth communication, having time to be with all family members and attention, so that the atmosphere of the house feels calm and warm. Such family harmony will reduce the busyness of teenagers outside who can influence them to act deviantly.

5. In the case that most influences student behavior, $59.28 \%$ of respondents stated that peers greatly influence respondents in their daily activities, even though there is more time to gather with family than to gather with peers.

6. Respondents feel it is necessary to be able to form a peer group that is useful for the place or place of interaction in terms of reminding each other about the dangers of drug abuse.

7. The form of activities that are most effective in disseminating the dangers of drug abuse can be done through lectures, dialogue and one-on-one face-to-face communication. 


\section{References}

Creswell, John W, 1994.Research Design: Qualitative and Quantitative Approach. California: Sage Publication.

Effendy, Onong Uchjana. 1993. Ilmu Teori dan Filsafat Komunikasi. Bandung. PT. Citra Aditya Bakti.

Rosdakarya.

1986. Dimensi-dimensi Komunikasi. Bandung,PT. Remaja

Hurlock, E.B. 2002. Psikologi Perkembangan. 5th edition. Erlanga: Jakarta

Kriyantono, Rachmat, 2007. TeknikPraktisRisetKomunikasi, Jakarta: Kencana.

Liliweri, Alo. 1991. Komunikasi Antarpribadi. Bandung : Citra Aditya Bakti.

Moleong , 2005. Metodologi Kualitatif Edisi Revisi. Bandung: PT Remaja Rosdakarya

Papalia, old. 2001. Perkembangan Pada Remaja. Jakarta : Rineka Cipta

Prawirosudirjo. 2003. Menginjak Masa Remaja. Jakarta : Bhratara Karya Aksara.

Rakhmat, Jalaludin. 2002. Psikologi Komunikasi. Edisi Revisi. PT.Remaja Rosdakarya. Bandung. 1999. MetodePenelitianKomunikasi. Bandung, PT. RemajaRosdaKarya.

Rumini, Sri dan Siti Sundari. 2004. Perkembangan Anak dan Remaja. PT Rineka Cipta, Jakarta.

Santrock. J. W. 2002. Life-Span Development: Perkembangan Masa Hidup.(edisi kelima) Jakarta: Erlangga

\section{Other Resources}

Undang-Undang No. 22 tahun 1997 tentang Narkotika

Medan Dalam Angka 2012 